УДК $821.161 .2 \ll 19 »$

DOI https://doi.org/10.26661/2414-9594-2020-2-30

\title{
РЕЦЕПЦІЯ ВІРШОЗНАВЧИХ ТЕРМІНІВ ЯМБА ТА ХОРЕЯ В УКРАЇНСЬКІЙ ПОЕТОЛОГІЧНІЙ ЛІРИЦІ (СПЕЦИФІКА ОЦІННОЇ ІДЕНТИФІКАЦІЇ)
}

\author{
Фінчук Г. В. \\ кандидат педагогічних наук, дочент, \\ дочент кафедри іноземних мов \\ Рівненський державний базовий медичний коледж \\ Рівненської медичної академії \\ вул. М. Карнаухова, 53, Рівне, Україна \\ orcid.org/0000-0003-4338-7885 \\ Albateur@rambler.ru \\ Зубілевич М. I. \\ кандидат педагогічних наук, дочент, \\ доцент кафедри суспільно-гуманітарних дисииплін \\ Рівненська медична академія \\ вул. М. Карнаухова, 53, Рівне, Украӥна \\ orcid.org/0000-0003-4338-7885 \\ marynazubilevych@gmail.com
}

Ключові слова: віршознавча
термінологія, поетологічна
рецепчия, лірика, ямб, хорей.
Наукову розвідку присвячено дослідженню специфіки оцінної ідентифікації поетологічних рефлексій віршознавчих термінів (ямба і хорея) в українській ліриці XIX-XX століть. До поетологічної лірики відносимо такі поетичні твори, які містять тематично декларовані авторські рефлексії та саморефлексії стосовно тих або тих психологічних аспектів формування та плину творчого процесу. Феномен поетології слід відокремлювати від спорідненого з ним, але у смисловому сенсі більш широкого поняття металітературності, яке має на увазі не лише виявлену в тексті художнього твору певну форму авторської творчої рефлексії, але й суто теоретичні роздуми письменника, оформлені у вигляді різноманітних коментарів, зауважень, статей літературознавчого характеру.

У статті проаналізовано та узагальнено два сюжетні типи авторської рефлексії віршознавчих термінів у текстах поетологічної лірики - цілісно-сюжетний та фрагментарно-сюжетний. 3'ясовано, що в текстах першого типу авторська поетологічна рецепція реалізована або власне в контексті віршознавчої тематики, або в білыш широкому контексті поетичної творчості загалом.

Переважна більшість проаналізованих поетологічних текстів відноситься до другого - фрагментарно-сюжетного типу. Семантична модель, за якою відбувається рецепція віршознавчих термінів у текстах цього типу, як правило, побудована у формі асоціативно-образного співвідношення їхніх семантичних ознак із предметно-тематичною сферою певної людської життєдіяльності. 3'ясовано, що пріоритетними для подібних образно-асоціативних зіставлень у проаналізованих текстах поетологічної лірики виступають три предметнотематичні сфери людської життєдіяльності: кохання, природне оточення людини, ситуативні деталі побутового життя.

Встановлено, що специфіка авторської оцінної ідентифікації віршознавчих термінів вукраїнській поетологічнійліриці спрямованана: 1)рефлексії, пов'язані 3 особливостями метро-ритмічної структури двоскладових стоп; 2) асоціації на означення фонологічної та вербальної семантики двоскладових стоп; 3) рецепцію індивідуальної поетичної практики використання двоскладових стоп; 4) екзистенційно-ціннісні характеристики семантики двоскладових стоп. 


\title{
THE RECEPTION OF POETIC TERMS IAMB AND TROCHEE IN UKRAINIAN POETIC LYRICS (SPECIFICS OF EVALUATIVE IDENTIFICATION)
}

\author{
Finchuk H. V. \\ Candidate of Pedagogical Sciences, Associate Professor, \\ Associate Professor at the Department of Foreign Languages \\ Rivne State Basic Medical College \\ of the Rivne Medical Academy \\ M. Karnaukhova str., 53, Rivne, Ukraine \\ orcid.org/0000-0003-4338-788 \\ Albateur@rambler.ru \\ Zubilevich M. I. \\ Candidate of Pedagogical Sciences, Associate Professor, \\ Associate Professor at the Department of Social Humanities Disciplines \\ Rivne Medical Academy \\ M. Karnaukhova str., 53, Rivne, Ukraine \\ orcid.org/0000-0003-4338-788 \\ marynazubilevych@gmail.com
}

Key words: poetic terminology, poetic reception, lyrics, iamb, trochee.

\begin{abstract}
Scientific research is devoted to the study of the specifics of the evaluative identification of poetic reflections of poetic terms (iamb and trochee) in the Ukrainian lyric poetry of the XIX-XX centuries. Poetical lyrics includes such poetic works that contain thematically declared author's reflections and self-reflections on certain psychological aspects of the formation and course of the creative process. The phenomenon of poetology should be separated from the related, but in the semantic sense of the broader concept of literature, which implies not only to find out in the text of a work of art a certain form of authorial creative reflection, but also purely theoretical reflections of the writer articles of a literary nature.

The article analyzes and generalizes two plot types of author's reflection of poetic terms in the texts of poetic lyrics - integral-plot and fragmentary-plot. It was found that in the texts of the first type the author's poetic reception is realized either in the context of poetic themes, or in the broader context of poetic creativity in general.

The great majority of the analyzed poetic texts belongs to the second - fragmentaryplot type. The semantic model, according to which the reception of poetic terms in texts of this type takes place, is usually constructed in the form of an associativefigurative correlation of certain semantic features with the subject-thematic sphere of a certain human life. It was found that the priority for such image-associative comparisons in the analyzed texts of poetic lyrics are three subject-thematic spheres of human life: love, the natural environment of man, situational details of everyday life. It is established that the specifics of the author's evaluative identification of poetic terms in Ukrainian poetic lyric poetry are aimed at: 1) reflections related to the peculiarities of the metro-rhythmic structure of two-syllable feet; 2) associations to the definition of phonological and verbal semantics of two-syllable feet; 3) reception of individual poetic practice of using two-part feet; 4) existential-value characteristics of the semantics of two-syllable feet.
\end{abstract}

Постановка проблеми. Поряд із досвідом уже традиційного - теоретичного - осмислення питань версифікаційної техніки та віршознавчої термінології в сучасному літературознавстві стверджується новий, досить перспективний і цікавий науковий напрям, пов'язаний із дослідженням практики так званих поетологічних рефлексій митців стосовно тих або тих аспектів поетики літературно-художнього твору. Широкий спектр питань поетологічної тематики художнього твору вже давно став предметом традиційного інтересу російських (Д. Сегал, В. Тюпа, Д. Бак, с. Бройтман, К. Штайн, М. Хатямова та ін.), західноєвропейських й англо-американських (Х. Вайнріх, 
Є. Мюллер-Зетельман, Х. Шлаффер, А. Вебер, В. Хінк та ін.) теоретиків літератури. Водночас в українському літературознавстві маємо лише поодинокі спроби цілісної теоретичної рецепції тих або тих аспектів дослідження поетологічного дискурсу (праці І. Лучука, О. Юферевої, Л. Артеменко тощо). «Однією із суттєвих ознак сучасного літературознавства, - зауважує О. Юферева, $-\epsilon$ тенденція до осмислення літературного процесу і творчої діяльності крізь призму авторської свідомості із супутніми феноменами: метаописом, авторефлексією, автореференцією тощо. На думку літературознавців, процеси творчого саморозкриття митця виходять на перший план, ферментують і структурують сучасну літературу, a їхнє дослідження прокладає шлях до розуміння індивідуальних текстових стратегій авторства» [2, c. 197].

Отже, метою статті $\epsilon$ дослідження специфіки оцінної ідентифікації поетологічних рефлексій віршознавчих термінів (ямба і хорея) в українській ліриці XIX - XX століть.

Виклад основного матеріалу. Насамперед, окремого теоретичного уточнення та узагальнення потребує термін «поетологічна лірика». Її доцільно було б класифікувати як окремий тематичний різновид лірики, об'єктом зображення якого виступають образно інтерпретовані автором у тексті твору питання, що стосуються загальних принципів та законів літературно-художньої творчості або специфіки їхнього практичного впровадження у власному поетичному досвіді.

Як констатують В.І. Тюпа та Д.П. Бак, самосвідомість літератури спрямована на «художне завдання»: «це не рефлексія самопізнання, а рефлексія самовизначення <..> Осмислити роль творця у виникненні художнього цілого - ще не знайденого, але вже привабливо привідкритого духовному погляду автора, - у цьому і полягає творча функція літературної саморефлексії» $[1$, c. 5$]$.

У процесі аналізу було спостережено застосування двох основних сюжетних типів авторської рефлексії віршознавчих термінів у текстах поетологічної лірики. Перший тип, який умовно можна назвати цілісно-сюжетним, передбачає введення до тексту твору більш або менш розгорнутої і предметно деталізованої сюжетної картини, тематично зв'язаної поетологічною рефлексією. Подібні тексти, що містять віршознавчі рецепції, в українській поетологічній ліриці кількісно не надто численні (І. Муратов «Ямбові»; I. Франко «Галицьким сонетистам»; Б.-І. Антонич «Будень», «Весілля»; I. Жиленко «Недуга»; М. Руденко «Як стати поетом»; Г. Світлична «Дівчинка Муза» та ін.).

Другий тип, який умовно може бути означений як фрагментарно-сюжетний, має вигляд епізодич- них мотивно-сюжетних вкраплень авторських віршознавчих рецепцій у текст, який у цілому не маркований поетологічною тематикою. Зазвичай подібні вкраплення в таких творах мають форму асоціативно-образного співвідношення певних ознак віршованого твору з різними предметно-тематичними сферами людської життєдіяльності. Пріоритетними серед них, за нашими спостереженнями, $є$ три предметно-тематичні сфери людської життєдіяльності: кохання (С. Гординський «3 листів», С. Караванський «Дружині», Є. Маланюк «Парастас», Д. Павличко «Земля покрита білою габою» та ін.), природне оточення людини (В. Самійленко «Вже годі плакати...», I. Вирган «Осінні ямби», I. Муратов «Серпневі ямби», О. Забужко «Нічний трамвай» та ін.), ситуативні деталі побутового життя (А. Малишко «А зуби рвати? Насолода!», Л. Первомайський «Обирав я свою дорогу...», М. Руденко «Не нарікаймо на те, що вчинено...» та ін.).

Специфіка рецепції віршознавчих понять у текстах поетологічної лірики, крім окреслених типів їхнього сюжетно-тематичного вияву, реалізується також і в контексті певної художньої модальності, тобто авторської оцінної ідентифікації уживаних ним термінологічних номінацій.

Спектр різноманітних поетологічних ідентифікацій ямба i хорея, виявлений у корпусі досліджуваних віршованих текстів (попри певний схематизм подібних класифікацій), можна систематизувати за такими ознаками: 1) рефлексії, пов'язані 3 особливостями метро-ритмічної структури двоскладових стоп; 2) асоціації на означення фонологічної та вербальної семантики двоскладових стоп; 3) рецепція індивідуальної поетичної практики використання двоскладових стоп; 4) екзистенційно-ціннісні характеристики семантики двоскладових стоп.

1) Рефлексії, пов'язані 3 особливостями метро-ритмічної структури двоскладових стоп. Подібний тип рефлексій грунтується на асоціативному уподібненні метричної структури двоскладових розмірів таким життєвим процесам, які містять більш або менш чітко відстежувані ознаки ритмічної організації, зокрема:

- людська хода: Б.-І. Антонич «Пісня змагунів» (Гімнастичний крок гуркотить на грищі, наче тарабан; це вистукуємо наш залізний ямб), $€$. Маланюк «Напис на книзі віршів» (Важкі ma мускулясті стопи Пруживий одбивають ямб), М. Бажан «Спомин про Бернса» (Прийдешніх, неминучих літ, I крок, мов ямб, чітким дзвенінням Квадратний міряе граніт), І. Муратов «Ямбові» (Долає точність $і$ наочність Твоїх карбованих рядків);

- pyx у природі або техніці: Б. Кравців «Чужиною» (В ширінь безкраю степової стяги Вистукує 
дорогу клично ямб), М. Сингаївський «Як перші незабутні букварі...» (I від чіткої, пружної ходи хитаються $і$ ямби, $і$ хореі), «Спрага» (Поїзди цокотять, наче ямби, над країною наших дум), Яр Славутич «Мої слова, добірні й прості...» (Moi стрункі й суворі ямби Течуть ностальгією хвиль На бурі скелі й темні дамби);

- людська праця: М. Рильський «Я і Київ» (Тесать, рубати, будувать, Охоти теслям додавать Тугими приструнками ямба), Ю. Клен «Попіл імперій» (i скарано мене, як Прометея: ией трунт копає вже чимало літ лопата в ямба такт і такт хорея);

- фізіологічні процеси, зокрема робота серця: Є. Маланюк «Як гірко пахнуть липи, що колись...» (В ямбічний стукіт двох сердець...), с. Гординський «3 листів» (I серие спіймане у мить Таку вдаряти хоче ямбом); пульсу: с. Гординський «Глиб» (Б'є пульсу гнівного ямбічний маятник); дихання: Є. Маланюк «Мій ямб задиханий, моє горіння гнівне...», I. Драч «Пошта» (Напиши лиш подихом, подиши Тим твоїм трояндовим, молодим, А я тобі ямбовим - сивий дим); кровообігу: Б. Кравців «Майбутнє» (Та б 'ється кров твердого ямбу молотком);

- симетрія побудови, співвіднесена з порядком військовим: А. Загравенко «Призов» (По-братньому зімкнулись ескадрони в чіткому і красивому строю бійців, що їхні ямби дзвінкотонні служили людству не в однім бою), Д. Кремінь «Щодня» (Немов когорти римські, ямби...), І. Драч «Останній міст полковника» (Місячи порох чобітьли яловими, Незугарною рухливою скульптурою Виріс він перед рядами ямбовими); природним: М. Руденко «Все розміряно та розписано...» (Ізаселено грішні лисини Під лінійку Сосновими ямбами. Ці дерева запрограмовані Ходять правильними колонами, - Як словесні рядки, Заримовані Віршотвориями); ментальним: І. Світличний «Клясичний вірш» (Гвардійська виправка ідеї. Парад римованих думок. Стопа в стопу, рядок в рядок Карбують ямби і хореі), О. Жолдак «Речне слово» (Ямбовані рядки і думи достеменні, Критичні ірища любові й зненавид);

- ритмічний рахунок: Ю. Клен «Попіл імперій» (Біля шведської могили, де я сірим вечором гуляв, пан мені зустрівся милий, що на пальиях ямби скандував), В. Квасновський «3 мороку до світла» (По ночах колисав я кволі рими, А ямби рахував, щзоб не згубились) або недотримання його правил: Г. Світлична «Дівчинка Муза» (Говорила, щзо втратив розум Через неї один поет: Написав анапестом прозу Й хореїчний створив сонет).

2) Асоціації на означення фонологічної та вербальної семантики двоскладових стоп. $\mathrm{У}$ даному типі рефлексій предметом асоціативного зближення $є$ індивідуально інтерпретована в поетичному творі звукова та словесна специфіка ямба або хорея. Вербальна специфіка пов'язана 3 авторськими образними асоціаціями між ямбом та співвіднесеними 3 ним засобами словесного вираження:

- в індивідуальній поетичній практиці: М. Драй-Хмара «Я світ увесь сприймаю оком...» (Люблю слова... Enimem серед них - як напасть: уродиться, де й не чекав, і тільки ямби та анаnест nотроху бережуть устав), А. Малишко «Зерно» (Hi, не ямбами, не хореями Диха слово між масами), I. Калинець «Полум'яні посли» (Коли забракне слів і не рятують ямби, до тебе илю послів - полум'яні троянди), Л. Мельник «Майже епітафія» (Їй колись приурочать оди безсловесних шедеврів ямби), «Піввірш» (Який там ямб! Слова напівживі);

- y персонірікованих образах природної сфери: М. Сингаївський «Іванова райдуга» (І на причілку клен безтурботний лепетав до них свойм тристопним ямбом), І. Андрусяк «Троянда для Піночета» (Осінь не плаче, в пазусі осінь має корону, лузає сім'я, плодить бацили, ходить по колу, лається ямбом).

Фонологічна специфіка стосується насамперед суб'єктивно асоційованих характеристик звучання ямба й хорея, ідентифікованих за ознаками:

- дзвінкості: І. Франко «Епілог» (П'ятистоповий ямб, мов з міді литий, Два з чотирьох, дваз трьох рядків куплети, Пов 'язані в дзвінкі рифмові сплети), І. Франко «Галицьким сонетистам» (Штирнадиять вірмів, но п'ятиямбових, I n'ять пар римів звучно-криштальових), М. Бажан «Спомин про Бернса» (І крок, мов ямб, чітким дзвенінням Квадратний міряє граніт);

- зв'язку з музикою: Ю. Клен «Східняцьке фуріозо» (коли я йшов сюди $і$ в сірій торбі беріг ямбічну музику октав), В. Базилевський «Нема поета, що сказав слова ці...» (Та чути в ямбах гул маніфестачій і музику неосягненних сфер);

- зіставлення зі звуковою сферою природного оточення: В. Комашков «Картинка» (Ластівка розтягує свої хореї, кінчаючи жіночою римою, виспівує себе й місие для гніздечка під дахом).

3) Рецепція індивідуальної поетичної практики використання двоскладових стоп. Така рецепція стосується оцінної характеристики двоскладових стоп стосовно їхнього використання у творчості того чи того поета або у власній творчості.

Характеристика поетичної практики інших nоетів представлена творами: Бабая (Б. Нижанківського) «Невідома птиця» (Клясичний ямб y Кленовім сонеті), М. Бажана «Спомин про Бернса» (Іде, осяяний видінням Прийдешніх, неминучих літ, I крок, мов ямб, чітким дзвенінням Квадратний міряе граніт), Л. Дмитерка 
«Любили ямб співці великі» (Любили ямб співиі великі I шліфували, мов граніт), Л. Забашти «Я радію, що маю свій унікальний сад...» (Коли набридають ямби й верлібри Верхарна й Верлена, Я протоптую стежку до озера Тиші $i$ Чистоти), В. Базилевського «Хіба я не жив ще до нашої ери?..» (вояк-волоиюгга, бродяга, нетяга вигупує ямбом мій брат Архілох).

Образи віриознавчої авторецепції знаходимо в поетичних текстах: Б.-І. Антонича «Ніч» (Не хочу більш писати віршів, складати ямби та трохеі), «Весілля» (Почалось так: упився я від перших власних строф похмілля... Так народились перші ямби), «Будень» (В годині n'ятій рано зірватись жваво з ліжка... Тепер на хвалу Божу складати прості ямби), «Наївність» (Що ие кого иікавить, щчо я складаю ямби? Одне сказав я вам би: для Божої все слави), В. Базилевського «Немов сундук, який забитий крамом...» (голова забита рам'ям віршів, уривками, рядками, чаром звуків, протяжним гулом дактилічних рим, мінливих ритмів, ямбами дзвінкими, гекзаметрами, мотлохом метафор, уламками балад, елегій, стансів, ошматтями сонетів і поем), П. Гірника «Мабуть, не скажуть: має власний голос...» (Мабуть, не скажсть: має власний голос. Старенькі рими, вивірений ямб).

4) Екзистенційно-ціннісні характеристики семантики двоскладових стоп. Рецепції такого роду передбачають оцінну ідентифікацію віршознавчих термінів у розрізі певного емоційного коду авторських почуттів, що виявлені в поетичному творі: $\mathrm{C}$. Маланюк «Сучасники» (Ще молитесь, далекий брате, Серед Звенигородських піль. Ще не стомились карбувати В коштовних ямбах вічний біль), «Ода до прийдешнього» (I коли доба метальним словом Збудить в сериі переможний ямб), «Ти не знала, що я - пломінний...»
(Божевільно клекочуть ямби - Аж тепер я тебе пізнав!), О. Гончар «Ямб» (Тебе, розхристаний мій ямб, Як дівчину, забуду), С. Гординський «Два вірші на одну тему» (Кидай латаття своє, верболози і знуджений ямб), І. Муратов «Ямбові» (Мій друже ямбе, ритм єдиний), В. Гаврилюк «Яка нудьга...» (Яка нудьга всі иі ямби, ямби $i$ трохеї... i ваша метафоричність, $i$ дактиль, $i$ спондей), В. Малишко «Тремтливість» (Така крізь серие ніжність пророста, Нема для неї слів, немає жестів, Ні дактилів, хореїв, анапестів, Така велична і така проста).

Висновки і перспективи подальших досліджень. У статті окреслено теоретичні ознаки терміна «поетологічна лірика», узагальнено та досліджено основні типи оцінної авторської рефлексії віршознавчих термінів ямба та хорея на матеріалі української поетологічної лірики XIX - XX століть. Спостережено використання двох сюжетних типів авторської рефлексії віршознавчих термінів: цілісно-сюжетного та фрагментарно-сюжетного, відмінних за ступенем предметної деталізації поетологічної тематики. Тематично-оцінний спектр рецепції віршознавчих термінів ямба і хорея в українській поетологічній ліриці класифіковано за такими ознаками: 1) рефлексії, пов'язані з особливостями метро-ритмічної структури двоскладових стоп; 2) асоціації на означення фонологічної та вербальної семантики двоскладових стоп; 3) рецепція індивідуальної поетичної практики використання двоскладових стоп; 4) екзистенційно-ціннісні характеристики семантики двоскладових стоп.

Перспективи подальших досліджень теми стосуватимуться поглиблення та розширення спектру віршознавчих рецепцій, виявлених в українській поетологічній ліриці.

\section{ЛІТЕРАТУРА}

1. Тюпа В. И., Бак Д. П. Эволюция художественной рефлексии как проблема исторической поэтики. Кемерово: КемГу, 1988. С. 4-15.

2. Юферева О. В. Поезія в системі метакатегорій. Вісник Житомирського державного університету ім. I. Франка. 2011. № 56. С. 197-201.

\section{REFERENCES}

1. Tyupa V.I., Buck D.P. Evolution of artistic reflection as a problem of historical poetics. Kemerovo : KemGu, 1988. S. 4-15.

2. Yufereva O.V. Poetry in the system of metacategories. Bulletin of Zhytomyr State University. I. Franko. 2011. № 56. S. 197-201. 